\title{
LAND SUBSIDENCE INDUCED BY THE OVEREXPLOITATION OF THE AQUIFERS IN KALOCHORI VILLAGE - NEW APPROACH BY MEANS OF THE COMPUTATIONAL GEOTECHNICAL ENGINEERING
}

\author{
Loupasakis C. ${ }^{1}$ and Rozos D. ${ }^{2}$ \\ ${ }^{1}$ National Technical University of Athens, School of Mining and Metallurgical Engineering, Laboratory of \\ Engineering Geology and Hydrogeology, 9, Heroon Polytechniou Str 157 80, Zografou (Athens) Greece, \\ cloupasakis@metal.ntua.gr \\ ${ }^{2}$ National Technical University of Athens, School of Mining and Metallurgical Engineering, Laboratory of \\ Engineering Geology and Hydrogeology, 9, Heroon Polytechniou Str 157 80, Zografou (Athens) Greece, \\ rozos@metal.ntua.gr
}

\begin{abstract}
Land subsidence induced by the overexploitation of the aquifers in Kalochori village has been occurring since 1965. The excessive water pumping led to the development of surface subsidence reaching, in several areas, the maximum values of 3 to $4 \mathrm{~m}$. The evaluation of the geological, geotechnical and hydrogeological setting of the wider Kalochori region as well as the historical background of the subsidence phenomena provided variable data, which were finally used for the study of the phenomenon by means of a finite element method simulation. The availability of the various geodetic records allowed the cross-checking of the results and the conduction of all necessary back analyses. Also, the knowledge of the land use distribution and the activities taking place in the wider Kalochori region helped the rational interpretation of the phenomenon and the detection of its causal factors.
\end{abstract}

Key words: land subsidence, FEM simulation, aquifers' overexploitation, geo- hazards.

\section{Introduction}

The increasing need for water, during the last decades, led to the overexploitation of aquifers in several regions in Greece. The overexploitation of aquifers susceptible to compaction led to the manifestation of land subsidence, in areas like Thessaly plain, Kalochori village, Megalopolis, Anargiri region (on the southwest of Florina) and Messara valley.

One of the first noticed land subsidence phenomenon in Greece is that in Kalochori region. Kalochori village occupy the lowlands between the delta of Gallikos river and the west side of Thessaloniki (Fig. 1). In the 1960`s the wider Kalochori region became the main industrial centre of the area, leading to the increasing need of water, covered by productive wells. The overexploitation of the aquifers was also enchased by the excessive water pumping conducted by the Water Company of Thessaloniki (Fig. 1). The subsidence phenomena in Kalochori region were first noticed in the early 1960 `s. Since then, the morphological and the environmental setting of the region changed violently.

The land subsidence phenomena in Kalochori region have been studied during the last 25 years by many researchers. The majority of the researchers credit the subsidence mainly to the compaction 


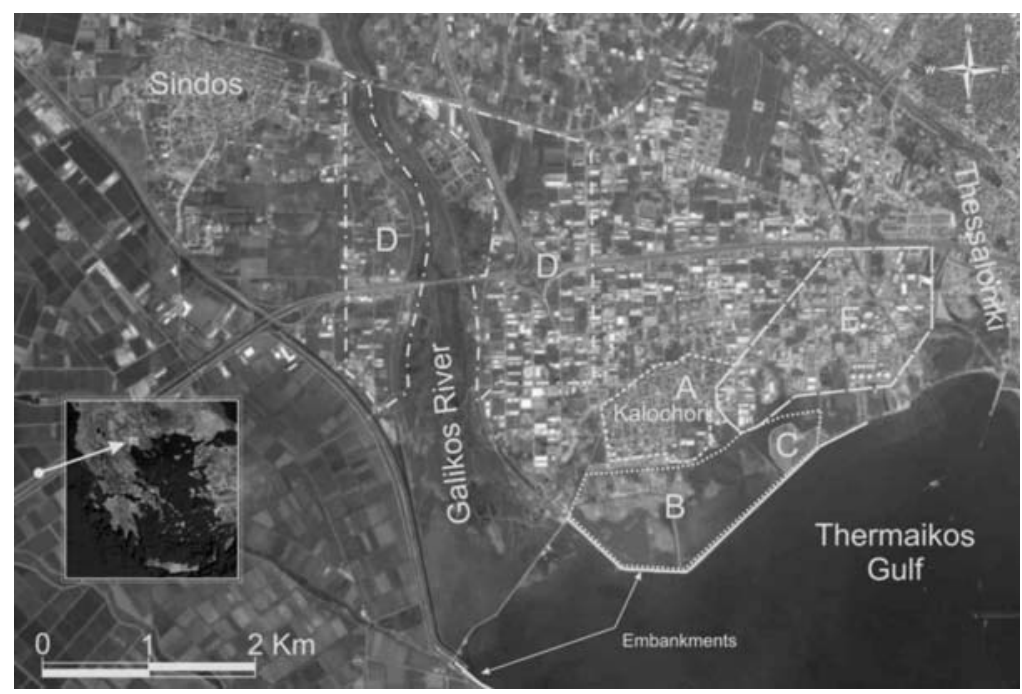

Fig. 1: Satellite picture (Google Earth) presenting the Kalochori Village in relation to Thessaloniki as well as the land use distribution in the wider region. The outlines enclose the following areas: A: Kalochori village, B: lagoon, C: waste dumping site, D: Water Company's productive wells areas, E: industrial area until the 1980`s. Today the industries occupy almost all the wider Kalochori area.

of the reservoirs (Andronopoulos et al., 1990 \& 1991, Hatzinakos et al., 1990, Rozos et al., 1993), although many other interpretations have also been expressed. Psimoulis et al. (2006) attributed the subsidence phenomenon to a large scale natural effect on which smaller scale anthropogenic effects, like water pumping induced compaction, are superimposed. Doukakis (2005) expressed the opinion that the rapid sea intrusion, beside the land subsidence, is amplified by the coastline erosion and by the sea level rising caused by the climate changes. Dimopoulos (2005) claimed that the subsidence phenomena in Kalochori region are caused by the consolidation of the loose silty-clay deposits and by the flowing sand phenomenon taking place close to the coastline. Stiros (2001) expressed that apart from the reservoirs` compaction, possible additional causes of the ground subsidence are: a) the consolidation of near-surface sediments, b) the oxidation of peat soils in the vadose zone, c) the synsedimentatary deformation of the delta, and d) the sub-surface instability of the delta front mud. The variety of the interpretations reveals the confusion that has been caused by the complexity of the phenomenon.

This study aims to coevaluate all available data provided by the numerouse studies conducted in the area, in order to examine the land subsidence by means of a computational geotechnical engineering methods. The various geodetic records allow the cross-checking of the results and the conduction of all necessary back analyses, in order to calibrate and evaluate the geotechnical parameters as well as the Finite element simulation model.

\section{Subsidence phenomena history}

In 1965 a progressive marine invasion was noticed and finally, in 1969, during a period of intensive rainfall, the seawater reached the village. For the protection of the village an embankment was constructed along the entire coastline. This construction collapsed in 1973 due to continuous deforma- 

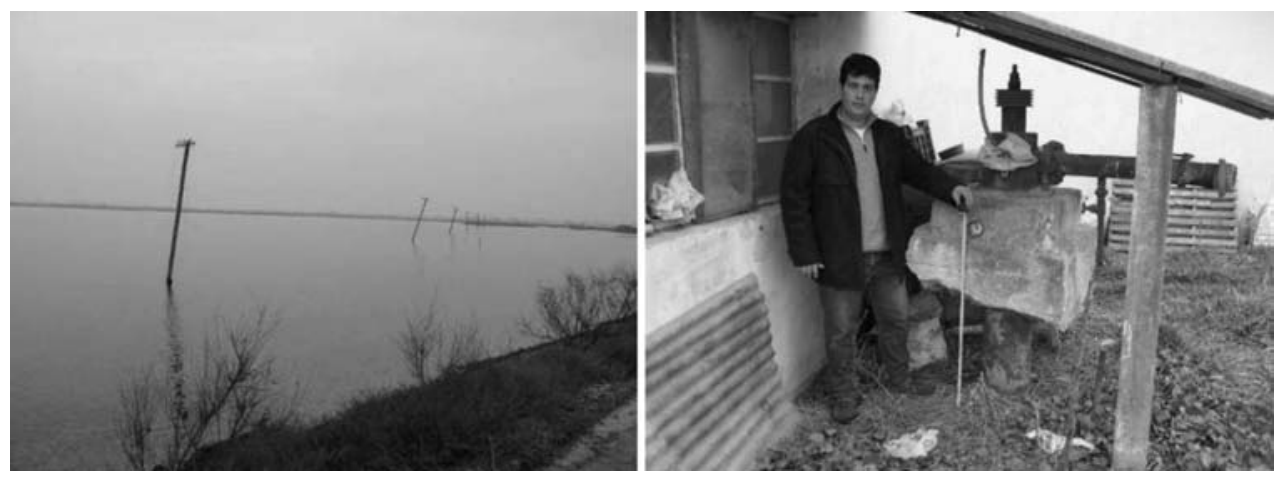

Fig. 2: (Left) Submerged remnants of the old electricity network constructed along the side of a road, SW of Kalochori, in1975. (Right) Emerged well`s pipes at a $100 \mathrm{~m}$ deep well located in the Institute of Wheat Cultivation (SW of Kalochori). The pipes have been extracted $0.8 \mathrm{~m}$ over the ground surface. The photos were taken in 2008 .

tions. In 1976 a new barrier was constructed in a forwarded position. Unfortunately three years later in 1979, after a storm, the embankment failed causing the re-flooding of the village. Finally, in 1980 a new larger dam was constructed. Since then several damages and extensions of the embankment were recorded, but the main construction managed to resist the subsidence deformations and the dynamic loading of the waves. This barrier is combined with an extensive surface draining network and several pumping-stations in order to prevent the inland from flooding.

Through the years several signs referring to the total amount of the subsidence were reported. Andronopoulos et al. $(1990,1991)$ reported that between 1964 and 1990 several basements were filled with gravels in order to prevent them from flooding, also the main square of Kalochori was reconstructed about $1.2 \mathrm{~m}$ higher for the same purpose. Further more, it was reported that in many wells the pipes were extracted up to $2 \mathrm{~m}$ over the surface. Some signs are still visible today (Fig 2).

Many researchers estimated subsidence deformations to exceed $3 \mathrm{~m}$ in several locations (Andronopoulos et al., 1990 \& 1991, Hatzinakos et al., 1990, Rozos et al., 2004). This estimation was finally supported by Stiros (2001), who compared the 1:5000 topographic diagrams for the period $1955-1980$ (Fig. 3A). By means of that process, besides the total deformations values, Stiros proved that, until the 1980`s, the maximum subsidence regions (subsidence $>3 \mathrm{~m}$ ) were coinciding with the areas containing the pumping wells of the Water Company of Thessaloniki (Fig. 1) and with the south-western section of the industrial area containing the most water-consuming industries. According to geodetic measurements conducted during the last 20 years the rate of subsidence in the wider study area varies from 2,8 to $13 \mathrm{~cm} / \mathrm{yr}$. particularly, based on measurements conducted by the laboratory of geodesy of the A.U.Th. (Badelas et al., 1996), from September 1992 to July 1995, the subsidence rate in Kalochori region ranged from -3 to $-13 \mathrm{~cm} / \mathrm{yr}$ (Fig. 3b). Also, Doukas et al. (2004), by measuring a leveling network consisting of 37 stations, for a period of ten years, $1992-2002$, estimated that the subsidence speed varied from $-2,8$ to $-5 \mathrm{~cm} / \mathrm{yr}$. Note that, in both case studies the greatest subsidence occurred in the SE area of Kalochori. So, during the last decade, due to the inactivation of the Water Company's wells, the deformed areas have moved to the SW section of the old industrial area (Fig. 1).

Concluding, taking into account the various studies conducted for Kalochori region, the total amount 


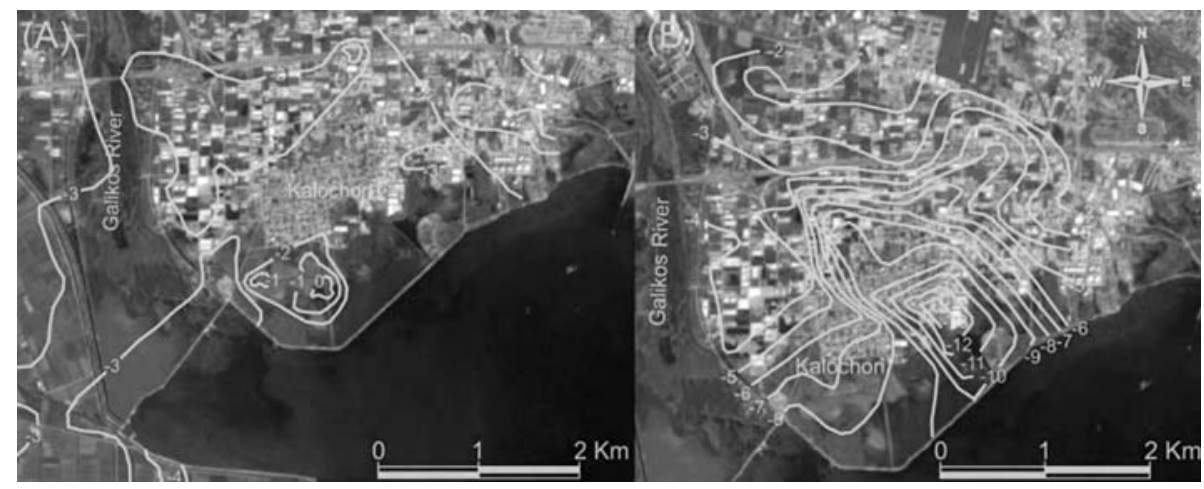

Fig. 3: (A) Equal subsidence contours, in meters, for the period 1955 - 1980 (Stiros, 2001). The $4 \mathrm{~m}$ contour, at the North of Kalochori, indicates an excavation. The $-2,-1$ and 0 contours, the south of Kalochori, indicates waste infill or earth-fill deposition. (B) Equal rate of subsidence contours (in cm/yr), from September 1992 to July 1995 (Badelas et al., 1996). The contours were plotted on Satellite images taken from Google Earth.

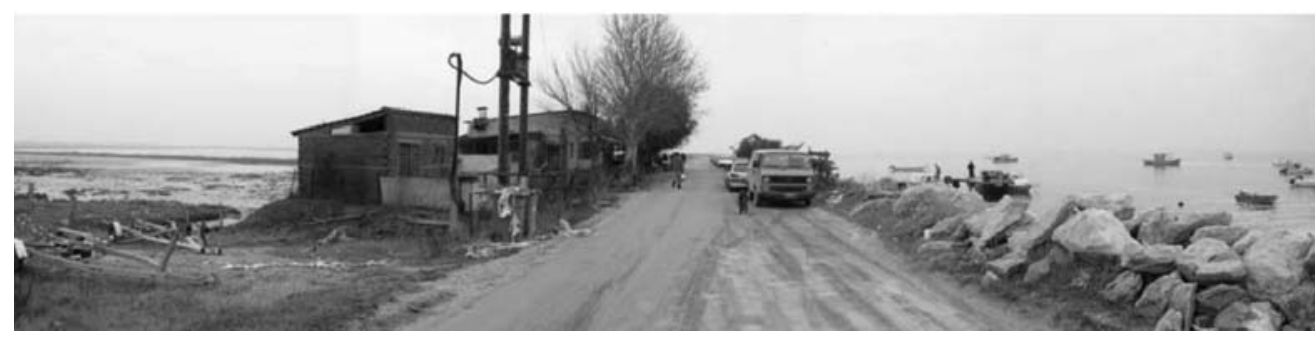

Fig. 4: View of the main embankment constructed in the South of Kalochori. On the right side of the embankment the sea level is about $0.5 \mathrm{~m}$ below the road level. On the left (interior) side, the lagoon water level is 4 to $5 \mathrm{~m}$ bellow the road level. Concluding, the inland is at least $4 \mathrm{~m}$ below the sea level.

of subsidence in the past 45 years must be reaching, in several areas, the maximum values of 3 to $4 \mathrm{~m}$. Furthermore, based on the same studies, the subsidence phenomenon keeps on developing at a mean rate of $-5 \mathrm{~cm} / \mathrm{yr}$. At the present time, extended areas along the coastline are located below the sea level (Fig. 4)

\section{Geological, Hydrogeological and geotechnical setting}

The upper formation of the study area (Hatzinakos et al., 1990, Rozos et al., 2000, 2004) is occupied by loose quaternary deposits. According to the geophysical investigation conducted by Nikolaou and Nikolaidis in 1987, those deposits extend down to a depth varying from 150 to $400 \mathrm{~m}$. Furthermore, based on additional data coming from the profiles of petroleum investigation drills (Demiris, 1988), carried out in the wider study area during 1962, the deeper strata are occupied by neogene deposits reaching down to a maximum depth of $600-700 \mathrm{~m}$. The neogene formations consist of silty sands and sands with silt, clay and infrequent fine gravel intercalations. 
According to the profiles of eight (8) geotechnical boreholes drilled in the Kalochori region (Andronopoulos, 1979, Andronopoulos et al., 1990), reaching down to depths varying from 20 to $90 \mathrm{~m}$, the quaternary deposits consist of clays, silty clays, sands and silty sands including organic material. The various in-situ and laboratory tests conducted on the core samples have given sufficient information about the physical and the mechanical properties of the above mentioned formations extended in the narrow study area

The lithostratigraphy of the sediments up to the depth of $90 \mathrm{~m}$ consists of the following formations: the top horizons, from the surface to a depth of 4.5 to $15 \mathrm{~m}$, are occupied by yellow-brown fine to medium grain sands and silty sands. Under the sands and down to a varying depth of 26.5 to 35.3 $m$ extends a black-gray silty sands horizon including organic materials. These impermeable silty sands constitute a barrier between the deep artesian aquifers and the unconfined shallow aquifer extending in the overlaying sands. The deeper horizons consist of brown sands and black-gray silty sands in alternations. The thickness of the interchanging layers varies from 5 to $50 \mathrm{~m}$ increasing proportionally to the depth. The brown sands are medium to coarse grain and in several depths thin silty sand intercalations are located. The diagenesis and the compaction degree of the above described sediments increase proportionally to the depth. Although there is not any available geotechnical information for depths over $90 \mathrm{~m}$, the geophysical investigation results and data coming from water drilling profiles showed that the above mentioned alteration routine continues down to the Neocene basement. A simplified typical cross section is presented in Fig. 9.

In agreement with the above described geological setting the formations of the wide study area contain one unconfined shallow aquifer extending in the overlaying sands and a system of successive confined - artesian aquifers developing below the impermeable black-gray silty sand layer, located under the top sand. At the deep confined, the aquiferous units are the brown sands, interrupted by thick black-gray silty sands intercalations.

The water table depth of the unconfined shallow aquifer fluctuates from 1.5 to $3 \mathrm{~m}$ and the quality of the water is very poor (Loupasakis et al., 1997; Soulios, 1999). This aquifer reaches down to a depth of 10 to $15 \mathrm{~m}$ and is widely used for meeting the needs of the farmers for irrigation water or occasionally as drinking water for cattle breeding purposes.

The first wells discharging the deep aquifers were constructed by the industries and by the Water Supply Company of Thessaloniki in 1955. Since then, the Water Company has constructed about 30 productive wells and the Kalochori village authorities 7 more, some of them reaching down to depths more than $200 \mathrm{~m}$. Further more, It is estimated that in the wider Kalochori area, during the last 50 years, more than 250 industrial wells have been operating. Most of these wells were drilled without the proper state permits. The great number of deep drills, points out the excessive discharge that has been taking place during the last decades in the wider area.

The piezometric surface of the aquifers, in the majority of drills constructed in Kalochori region during the 50s, was over the ground and the drills were artesian. Despite that, the overexploitation of the aquifers over the years caused the intensive drawdown of the piezometric surface and finally in 1981, it fell 37m (Andronopoulos et al., 1990). In the early 1980`s the water company abandoned the majority of the drills. Unfortunately, the authorities could not control the industrial drills, which were kept operating. Nevertheless, the reduction of the pumping wells led to the partial recovery of the piezometric surface level. According to measurements conducted during the period of 1997 2000 for a study commissioned by the Water Company (Soulios, 1999), the piezometric surface's level in the Kalochori region varied from 20 to $30 \mathrm{~m}$. The extreme variation points out the dynamic character of the aquifer caused by the continuous pumping. 


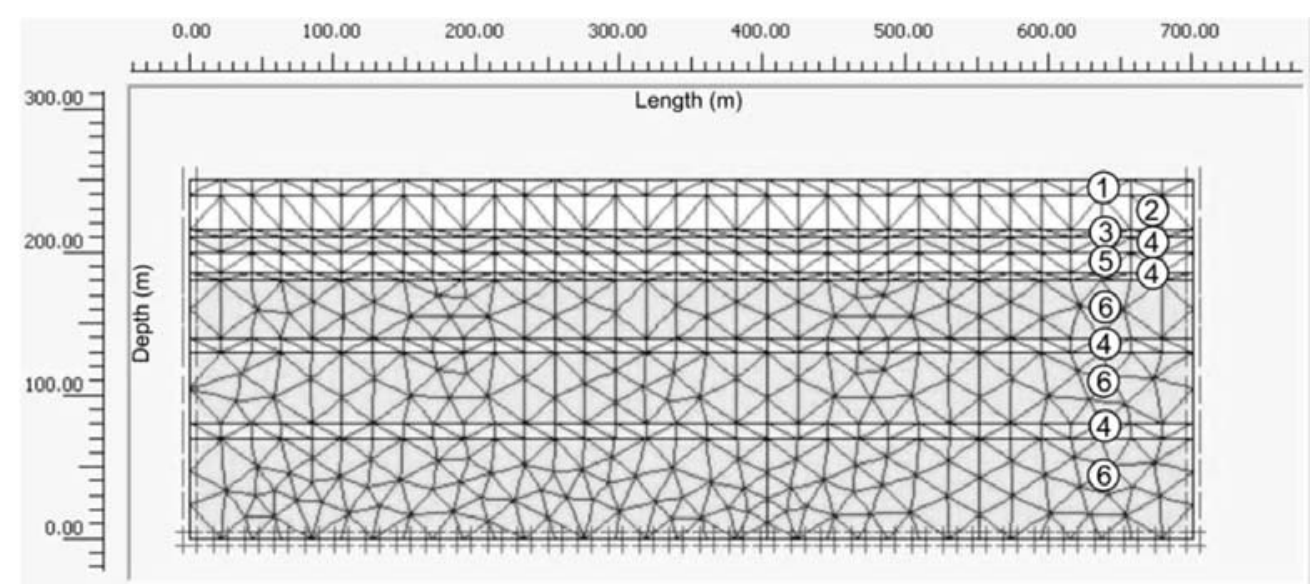

Fig. 5: Cross section of the simulated $250 \mathrm{~m}$ deep profile. The numbers correlate the soil data set parameters presented in table 1 with the horizons.

\section{Simulation procedure of the subsidence phenomenon}

The gradual drawdown of the piezometric surface for about $40 \mathrm{~m}$ definitely affected the pore pressure distribution in the overexploited confined aquifer formations. The pore pressure reduction could be considered responsible for the subsidence phenomenon. So, the simulation of the gradual piezometric surface drawdown in a typical profile, by means of finite or discrete element methods, could define the influence of the pore pressure reduction and could clarify the mechanism of the subsidence phenomenon. The numerous studies conducted for the Kalochori region provided plenty of data concerning the geological, the geotechnical, the hydrogeological setting as well as the historical background of the subsidence phenomena. These data covered all the requirements for setting up the polyparametric finite element simulation model applied in the present study. Furthermore, the availability of the various geodetic records allowed the crosschecking of the results and the conduction of all necessary back analyses, in order to calibrate the simulation model. These data appeared to be necessary and the model could not be applied without knowing them. Correspondingly, all these data could not be valuable without using a sophisticated polyparametric numerical analysis method as the one applied in this study. Practically, this case study was considered as the perfect chance of applying this FE method for the analysis of a water pumping induced subsidence phenomenon.

The simulation was conducted by using the PLAXIS (V 8.6) two - dimensional finite element code (Brinkgreve et al., 2002). This two - dimensional code could be considered sufficient as the present study practically deals with the simulation of a typical cross section with no horizontal transitions. The simulation procedure was applied in two characteristic profiles (Loupasakis \& Rozos, 2009). Combining the geological and hydrogeological setting, the maximum depth of the overexploited confined aquifers ranges between 150 and $250 \mathrm{~m}$. Therefore, the two typical profiles of 150 and $250 \mathrm{~m}$ were considered for the simulation of the subsidence phenomenon. The alteration and the thickness of the simulated geological formations is clearly presented in figure 5 and in table 1 and it is identical in both profiles. The only difference is that in the $150 \mathrm{~m}$ deep profile the bottom layers are missing. The width of the typical profiles was selected to be approximately three times bigger than their depth. Standard horizontal and vertical fixities were applied. The coarseness of the mesh was also selected to be fine in order to fit the narrow geological layers (Fig. 5).

The reevaluation of the available geotechnical data (Andronopoulos, 1979, Andronopoulos et al., 
Table 1. Soil data sets parameters.

\begin{tabular}{|c|c|c|c|c|c|c|}
\hline Parameter & $\begin{array}{c}\text { Yellow-brown } \\
\text { sands } \\
(1)\end{array}$ & $\begin{array}{c}\text { Black-gray } \\
\text { silty sands } \\
(2)\end{array}$ & $\begin{array}{c}\text { Brown sands } \\
\text { and silty sands } \\
(3)\end{array}$ & $\begin{array}{c}\text { Black-gray } \\
\text { silty sands } \\
(4)\end{array}$ & $\begin{array}{c}\text { Brown sands } \\
\text { and silty sands } \\
(5)\end{array}$ & $\begin{array}{c}\text { Brown sands } \\
\text { and silty sands } \\
(6)\end{array}$ \\
\hline Depth (m) & $0-10$ & $10-35$ & $35-40$ & $\begin{array}{c}40-50, \\
65-70,110- \\
120,170-180\end{array}$ & $50-65$ & $\begin{array}{c}70-110, \\
120-170, \\
180-250\end{array}$ \\
\hline Type & Drained & Drained & Drained & Drained & Drained & Drained \\
\hline$\gamma\left(\mathrm{kN} / \mathrm{m}^{3}\right)$ & 18,50 & 16,00 & 19,50 & 17,50 & 18,50 & 19,50 \\
\hline$\gamma_{\text {sat }}\left(\mathrm{kN} / \mathrm{m}^{3}\right)$ & 20,60 & 17,50 & 22,00 & 19,80 & 20,60 & 22,00 \\
\hline $\mathrm{k}_{\mathrm{x}}(\mathrm{m} / \mathrm{day})$ & 8,93 & 0,638 & 8,93 & 0,638 & 8,93 & 8,93 \\
\hline $\mathrm{k}_{\mathrm{y}}(\mathrm{m} / \mathrm{day})$ & 8,93 & 0,638 & 8,93 & 0,638 & 8,93 & 8,93 \\
\hline $\mathrm{E}_{\mathrm{ref}}\left(\mathrm{kN} / \mathrm{m}^{2}\right)$ & 16668 & 5400 & 19164 & 11250 & 16665 & 18570 \\
\hline $\mathrm{v}(-)$ & 0,25 & 0,20 & 0,25 & 0,25 & 0,25 & 0,30 \\
\hline $\mathrm{Gref}\left(\mathrm{kN} / \mathrm{m}^{2}\right)$ & 6666 & 2250 & 7667 & 4500 & 6668 & 7142 \\
\hline Eoed $\left(\mathrm{kN} / \mathrm{m}^{2}\right)$ & 20010 & 6000 & 22995 & 13501 & 19989 & 25005 \\
\hline $\mathrm{c}_{\text {ref }}\left(\mathrm{kN} / \mathrm{m}^{2}\right)$ & 10,00 & 60,00 & 35,00 & 80,00 & 10,00 & 40,00 \\
\hline$\phi\left({ }^{\circ}\right)$ & 38,50 & 7,00 & 40,00 & 15,00 & 38,50 & 40,00 \\
\hline$\Psi\left(^{\circ}\right)$ & 3,00 & 0,00 & 5,00 & 0,00 & 3,00 & 5,00 \\
\hline
\end{tabular}

1990) proved that the appropriate model for the simulation procedure was the elastic - perfect plastic model based on the Mohr - Coulomb failure criterion (Mohr - Coulomb model). The final values of the mechanical parameters selected for the simulation of the geological formations are presented in Table 1.

As mentioned, the piezometric level in the majority of the deep wells constructed in Kalochori region in 1955 was over the surface. Therefore, for the configuration of the models' initial pore pressure the confined aquifers' piezometric surfaces were set $5 \mathrm{~m}$ over the ground surface. On the contrary, the water table depth of the unconfined shallow aquifer was set $5 \mathrm{~m}$ below the ground surface and it was kept stable during the entire calculation procedure. Furthermore, a close flow boundary was applied at the base of the profiles.

The simulation procedure was divided in five calculation phases. During the first calculation phase, the piezometric level was reduced from $+5 \mathrm{~m}$ to $-10 \mathrm{~m}$ and during the next phases the level was increasingly reduced $10 \mathrm{~m}$ reaching down to the maximum depth of $-50 \mathrm{~m}$. The maximum piezometric level drawdown recorded during the years was $37 \mathrm{~m}$. In addition, the models were set to calculate the effect of an extra $10 \mathrm{~m}$ piezometric level drawdown, from -40 to $-50 \mathrm{~m}$, in order to study the effect of a hypothetical future development of the phenomenon. The calculations were carried out using the "plastic analysis" procedure - a typical elastic-plastic deformation analysis defined by the selected calculations model. Because of the slow deformation rates, it was considered that no excess pore pressure conditions were generated so the "drained behavior" setting was selected. The gradual reduction of the piezometric surface was applied by means of the "stage construction" routine. 


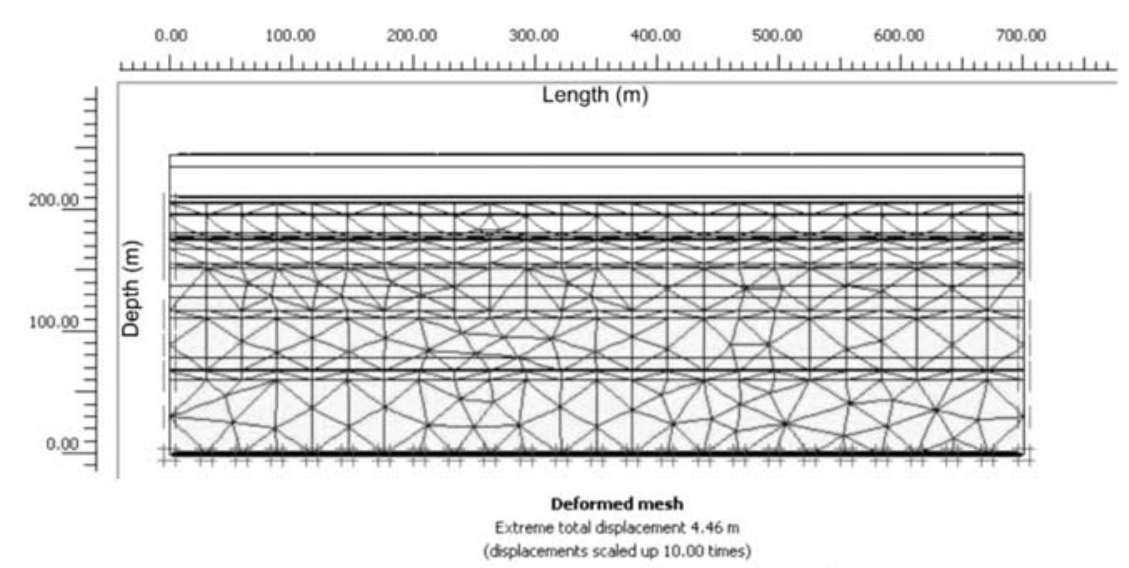

Fig. 6: Deformed mesh of the $250 \mathrm{~m}$ deep profile after the drawdown of the piezometric level $40 \mathrm{~m}$ under the ground surface.

\section{Simulation results}

The simulation results indicated that piezometric surface downgrading to the depth of $-40 \mathrm{~m}$ caused total deformations of -3.05 and $-4.46 \mathrm{~m}$ (Fig. 6) to the 150 and $250 \mathrm{~m}$ profiles, respectively. The deformations are in good agreement with those observed in the wider Kalochori region.

Except for the total displacements, the simulation procedure allowed the evaluation of the gradual piezometric surface downgrading effect and provided a complete set of displacement, strain, stress and pore pressure values for the various calculation steps (table 2). Regarding to the stress and the pore pressure values, the gradual reduction of the piezometric level causes a proportional reduction of the pore pressures and an increase of the effective principal stress. The preserved balance between the pore pressures and the effective stresses keeps the total principal stress stable. This helps understand the difference between the subsidence and the consolidation mechanism; the subsidence could occur without the application of additional external loads and it appears to be the result of the balance kept between the effective stresses and the pore pressure, when the water level drops.

Although the gradual reduction of the pore pressure led to an expected increase of the displacements (table 2), the rate of those deformations decreases in respect to the piezometric level redraw. As a result, although the deformations keep on developing, they gradually slow down as the formations reach to their maximum compaction level.

Despite the gradual decrease of the deformation rate, it was estimated that a $10 \mathrm{~m}$ additional reduction of the piezometric level, from -40 to $-50 \mathrm{~m}$, could cause extra deformations of -0.46 to $-0.79 \mathrm{~m}$ to the wider Kalochori region. Those deformations will cause problems to the embankments as in several sections they exceed the sea level less than $1 \mathrm{~m}$.

The step - vertical displacement graphs (Fig. 7) drawn for the various depths of the profiles, point out the expected gradual reduction of the displacements in respect to the depth. The differences occurred between the displacements in the various depths and through the same calculation steps, can be related to the emersion of the wells ' pipes occurred in the wider Kalochori area. Therefore, as presented in the $250 \mathrm{~m}$ deep profile (Fig.7), the deferential vertical displacements between the points located at the -10 and at $-110 \mathrm{~m}$ are $2.2 \mathrm{~m}$. This displacement could definitely justify the $0.9 \mathrm{~m}$ emersion of the $100 \mathrm{~m}$ deep well's pipes presented in Fig. 2. Note that the differences between the estimated deferen- 
Table 2. Maximum (Extreme) displacement, strain, stress and pore pressure values for the various piezometric level drawdown calculation steps in both simulation profiles.

\begin{tabular}{|c|c|c|c|c|c|}
\hline $\begin{array}{c}\text { Piezometric } \\
\text { surface level } \\
(\mathrm{m})\end{array}$ & $\begin{array}{c}\text { Maximum total } \\
\text { vertical } \\
\text { displacement } \\
(\mathrm{m})\end{array}$ & $\begin{array}{c}\text { Total phase vertical } \\
\text { displacement } \\
(\mathrm{m})\end{array}$ & $\begin{array}{c}\text { Maximum effec- } \\
\text { tive principal stress } \\
\left(\mathrm{kN} / \mathrm{m}^{2}\right)^{*}\end{array}$ & $\begin{array}{c}\text { Maximum total } \\
\text { principal stress } \\
\left(\mathrm{kN} / \mathrm{m}^{2}\right)^{*}\end{array}$ & $\begin{array}{c}\text { Maximum active } \\
\text { pore pressure } \\
\left(\mathrm{kN} / \mathrm{m}^{2}\right)^{*} \\
\text { Simulation }\end{array}$ \\
\hline \multicolumn{7}{|c|}{ Simulation profile reaching down $150 \mathrm{~m}$} \\
\hline-10 & -0.735 & -0.736 & $-1.6810^{3}$ & $-3.0710^{3}$ & $-1.4010^{3}$ \\
\hline-20 & -1.55 & -0.825 & $-1.7710^{3}$ & $-3.0710^{3}$ & $-1.3010^{3}$ \\
\hline-30 & -2.36 & -0.820 & $-1.8610^{3}$ & $-3.0610^{3}$ & $-1.2010^{3}$ \\
\hline-40 & -3.05 & -0.705 & $-1.9510^{3}$ & $-3.0510^{3}$ & $-1.1010^{3}$ \\
\hline-50 & -3.50 & -0.458 & $-2.0410^{3}$ & $-3.0410^{3}$ & $-0.99610^{3}$ \\
\hline \multicolumn{7}{|c|}{} & & Simulation profile reaching down $250 \mathrm{~m}$ & $-2.3910^{3}$ \\
\hline-10 & -1.08 & -1.08 & $-2.8510^{3}$ & $-5.2410^{3}$ & $-2.2910^{3}$ \\
\hline-20 & -2.25 & -1.18 & $-2.9410^{3}$ & $-5.2310^{3}$ & $-2.2510^{3}$ \\
\hline-30 & -3.40 & -1.16 & $-3.0310^{3}$ & $-5.2210^{3}$ & $-2.1910^{3}$ \\
\hline-40 & -4.46 & -1.07 & $-3.1210^{3}$ & $-5.2110^{3}$ & $-2.0910^{3}$ \\
\hline-50 & -5.24 & -0.7845 & $-3.2010^{3}$ & $-5.1910^{3}$ & $-1.9910^{3}$ \\
\hline
\end{tabular}

* Compression $=$ Negative
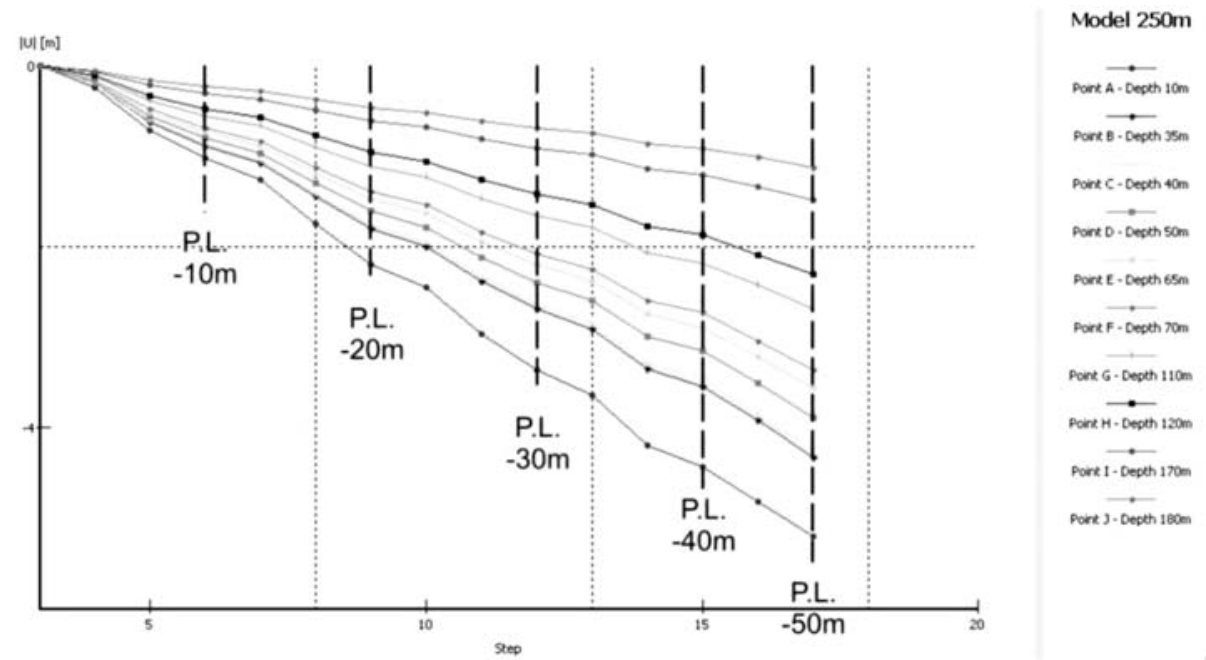

Fig. 7: Vertical strain - calculation steps curves presenting the development of the deformations in critical points appointed at the bases of the layers forming the $250 \mathrm{~m}$ deep profile. The vertical dashed lines point out the final calculation steps of the various piezometric level (P.L.) drawdown steps.

tial displacements and the occurred emersion of the pipes could be explained by the fact that, before the extraction of the pipes and because of their considerable weight, they should have statically penetrated the underlying formations maybe for more than one metre before they started emerging. 


\section{Concluding remarks}

Taking into consideration the results of the simulation the occurred excessive deformations can be attributed mainly to the overexploitation of the confined aquifers. Besides the encouraging results of the simulation, there are many other indications weakening the main theories of the, claimed by many researchers, near-surface deformations. The lack of deferential settlements, even in the oldest and the heaviest residential and industrial buildings, the development of the deformations in areas completely unloaded by manmade surface structures, the unchanged hydrological conditions of the shallow unconfined aquifer through the years, are some of the most important indications or facts weakening the above mentioned theories. If the near - surface sands or organic silty sands were susceptible to intensive settlements, this could have affected the surface constructions and the deformations could had been more intensive in areas occupied by residential or even more by heavy industrial buildings.

Concluding, the only way to reduce the deformation rate of the subsidence phenomena and protect the Kalochori region from further deformations, is to decrease and control the quantities of the extracted ground water.

\section{References}

Andronopoulos V. 1979. Geological and geotechnical study in the Kalochori (Thessaloniki) area. Institute of Geology and Mineral Exploration Report, Athens, p. 90.

Andronopoulos V., Rozos D., Hatzinakos I. 1990. Geotechnical study of ground settlement in the Kalochori area, Thessaloniki District. Institute of Geology and Mineral Exploration Report, Athens, p. 45.

Andronopoulos V., Rozos, D., Hatzinakos, I. 1991. Subsidence phenomena in the industrial area of Thessaloniki, Greece. In: Johnson, A. (Ed.). Land Subsidence, vol. 200. IAHS Publishers, pp. 59-69.

Badelas A., Savvaidis P., Ifadis I., Doukas I. (1996). Monitoring of ground subsidence in the area of Kalohori by using a high precision leveling control network. Technical Report No. 2853, Research Committee, Aristotle University of Thessaloniki, p. 157.

Brinkgreve, R.B.J., Broere, W., Waterman, D. (2006) Plaxis, Fine Element Code for Soil and Rock Analyses, 2D - Version 8, A.A. Balkema, Rotterdam Brookfield.

Demiris K. 1988. Geological settings and their influence on the development of the areas on the west of Thessaloniki. Proceedings of the symposium on the technical problems affecting the areas on the west of Thessaloniki, Technical Chamber of Greece, Thessaloniki.

Dimopoulos G. 2005. Investigation of the conditions generating soil settlements in Sindos - Kalochori area of Thessaloniki. In: Stournaras G., Pavlopoulos K., Bellos Th. (Eds.), Proceedings of the $7^{\text {th }}$ Hellenic Hydrogeological Conference and $2^{\text {nd }}$ MEM Workshop on Fissured Rocks Hydrogeology, Vol. 1, pp. 135-146.

Doukakis E. 2005. Costal red spots along the western Thermaikos gulf. Proccedings of the $9^{\text {th }}$ International Conference on Environmental Science and Technology, Rhodes island, Greece, pp. A334 - A339.

Doukas I., Ifadis I., Savvaidis P. 2004. Monitoring and analysis of ground subsidence due to water pumping in the area of Thessaloniki, Hellas. Proceedings of FIG Working Week, Athens, Greece. p. 14

Hatzinakos I., Rozos, D., Apostolidis, E. 1990. Engineering geological mapping and related geotechnical problems in the wider industrial area of Thessaloniki, Greece. In: Price, D. (Ed.), Proceedings of Sixth International IAEG Congress, Amsterdam, Balkema, pp. 127-134.

Loupasakis C., Sotiriadis M., Soulios G. 1997, Hydrochemical characteristics of the underground water of the plain area located between Thessaloniki and N. Halkidona, Proceedings of the $4^{\text {th }}$ Hydrogeological Congress of the Hellenic Hydrogeological Committee and the Association of Geologists and 
Mineralogists of Cyprus, Thessaloniki, pp. 194 - 212.

Loupasakis C., Rozos D., 2009, Land Subsidence Induced by Water Pumping in Kalochori Village (North Greece) - Simulation of the Phenomenon by Means of the Finite Element Method, Quarterly Journal of Engineering Geology and Hydrogeology, Geological Society of London, v. 42, No. 3; pp. 369382.

Nicolaou, S., Nicolaidis, M. 1987. Geoelectric study in Kalochori village of Thessaloniki, Institute of Geology and Mineral Exploration Report, Athens, p. 10.

Rozos D., Apostolidis E., Christaras B., (2000) Engineering - geological map of Thessaloniki wider area. Proceedings of national meeting on protection of Thessaloniki from natural hazards, 46-53.

Rozos D., Apostolidis E., Hatzinakos I. (2004) Engineering - geological map of Thessaloniki wider area, Greece. Bull. Eng. Geol. Env., 63. 103-108.

Rozos D., Hatzinakos I. 1993. Geological conditions and geomechanical behaviour of the neogene sediments in the area west of Thessaloniki (Greece). Proceedings of International Symposium on Geotechnical Engineering of Hard Soils - Soft Rocks, Greece. In: Anagnostopoulos et al (Eds.) Balkema, Rotterdam, Vol. 1 pp. 269-274.

Psimoulis, P., Ghilardi, M., Fouache, E., Stiros, S. 2007. Subsidence and evolution of the Thessaloniki Plain, Greece, based on historical leveling and GPS data. Engineering Geology, 90, 55-70.

Soulios, G. 1999. Research for the development of the aquifers in the low lands on the west of Thessaloniki for the interests of the Water Company of Thessaloniki. Research Committee Technical Report, Aristotle University of Thessaloniki, p. 99.

Stiros, S. 2001. Rapid subsidence of the Thessaloniki (Northern Greece) coastal plain, 1960-1999. Engineering Geology, 61, 243-256. 